\title{
WATER QUALITY OF THE BEACH IN AN URBAN AND NOT URBAN ENVIRONMENT
}

\author{
Y. VILLACAMPA ${ }^{1}$, I. LÓPEZ ${ }^{2}$, L. ARAGONÉS ${ }^{2}$, C. GARCÍA ${ }^{2}$, M. LÓPEZ ${ }^{2}$ \& A. PALAZÓN ${ }^{3}$ \\ ${ }^{1}$ Department of Applied Mathematics, Alicante University, Spain. \\ ${ }^{2}$ Department of Civil Engineering, Alicante University, Spain. \\ ${ }^{3}$ Department of Civil Engineering, Catholic University of Murcia, Spain.
}

\begin{abstract}
Numerous studies and theories have emerged for evaluating the quality of beaches using different parameters. In recent years in the European region, one of the most important aspects when evaluating a beach is the quality of water and sand. The quality of water is represented by the amount of Intestinal Enterococcus and Escherichia coli. This parameter is essential and others to obtain the Blue Flag, indicating that the user of the beach can swim safely. The European Directive 2006/7/EC establishes the limits of E. coli and Enterococcus that may exist in bathing water. However, it should be noted that each ecosystem is unique, and therefore the characteristics a beach are not the same per example if you are in an inland sea, or an ocean, or equal if they are close to an urban or a natural area. In this paper, 1,392 beaches in Spain have been analysed, and it has been observed that in the Mediterranean, the beaches have a lower concentration of bacteria than other areas. In addition, it appears that the sandy beaches and urban beaches have a higher content of bacteria that natural and gravel beaches.
\end{abstract}

Keywords: E. coli, enterococcus, natural, sand and gravel beaches, urban and semi-urban beaches, water quality.

\section{INTRODUCTION}

Spain is an eminent tourist country, where the sun and beach tourism occupies an important part of the sector. The beaches play a key role, because in them, most of the holiday activities of millions of tourists are developed annually. This means that a minimum of quality must be satisfied in coastal areas and especially in the waters, so that people who choose to enjoy the coast, do not compromise their health [1]. In order to preserve natural resources and public health, legislation brand guidelines to follow, through Directive 2006/7/EC of the European Parliament and of the Council concerning the management of the quality of bathing water is drawn.

One factor that makes the water quality is faecal bacteria Escherichia coli and Enterococcus. This type of faecal coliform are transmitted to humans through their faecal-oral cycle $[2,3]$. After discharge into the environment, these organisms can survive in the water column or associated with the particles being accumulated in sediments [4-6].

Several studies investigating the growth of $E$. coli in the sand [7,8], checking a rich organic, fine-grained sand, humid environment is conducive to persist, grow and lead to high densities of $E$. coli on the beach. In this regard, the turbidity of the water is correlated with the abundance of enteric bacteria, driven precisely the type of fracture and the sediment on the coast $[9,10]$.

The surroundings where the beach is located, it is also crucial to their quality, as several studies $[11,12]$ have shown that urban beaches have worse quality than natural or semi-urban. 
The objective of this research is will therefore study the relationship between the concentration of faecal bacteria, E. coli and Enterococcus, for the coastal area of Spain in the coastal bathing waters as well as the characteristics of the beach according to the type of sediment making up the beach, the degree of urbanization of the environment, population and population density of the municipality in which it is located.

\section{STUDY AREA}

The study area covers the entire Spanish coast, with notable differences between the Cantabrian, Atlantic and Mediterranean coasts, and its location in the North or South area (Fig. 1). Atlantic coasts are characterized by few coastal plains and be beaten by temporary high energy, with mild temperatures and high rainfall. They have large estuaries in Galicia and shorter in the Cantabrian area, with beaches on its banks. Strait area (South Atlantic) with a mild climate has abundant beaches and sand dunes. Canary Atlantic coast, are characterized by their volcanic origin, subtropical climate and low rainfall. The northern part is steeper and the southern beaches abound.

The Mediterranean coast, with mild winters and warm summers, presents a variety of coastal enclaves ranging from coastal lagoons (Albufera, Mar Menor), the dune ridges (Guardamar) through extensive beaches in Valencia or volcanic coast as Cape Gata with a rich vegetation associated with a semi-arid climate characteristics.

A total of 1,392 beaches along the Spanish coast were analysed. Of these, $74.5 \%$ of the beaches consist of sand (1,037), 6.3\% of the beaches are pure gravel (88) and 19.2\% (267) are at a combination of sand and gravel, as rated by Pye [13].

The $47.1 \%$ from the beaches of Spain are urban beaches, and this percentage is being somewhat higher in the Mediterranean region (53\% in the Northern Mediterranean and 60\% in the Southern Mediterranean). However, the natural beaches represent only $19.3 \%$ of the

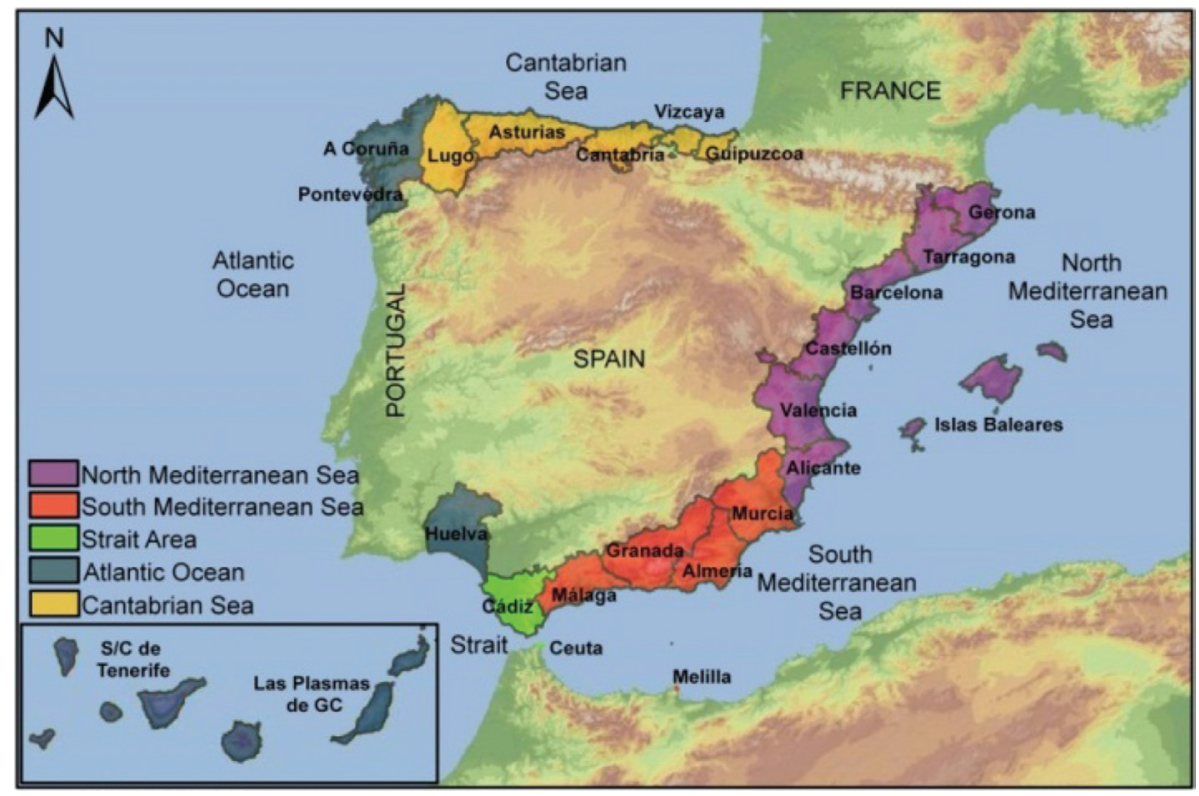

Figure 1: Location and grouping of the coastal provinces of Spain. 


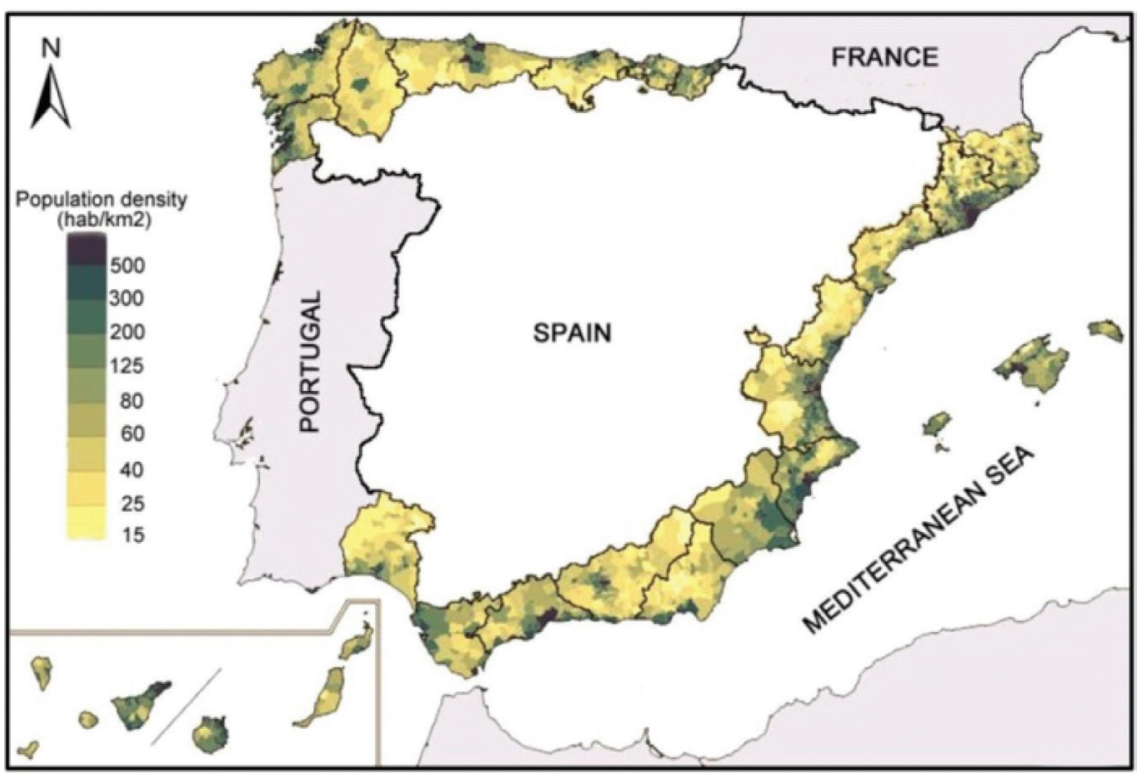

Figure 2: Population density in coastal provinces of Spain.

analysed beaches, being the Strait, which has the highest percentage of natural beaches (28\%), according to the classification of the urbanization level of Ariza et al. [14].

The 19 provinces seafront have a third of the Spanish surface and $60 \%$ of the population. Its density is twice the national average, ranging from 100 to more than 500 inhabitants per $\mathrm{km}^{2}$. However, not all the coast has a uniform density, there are areas that are large concentrations of population: the Galician Rías, points of the Asturias coast, Cantabria and Basque, Barcelona and its surrounding area, orchards Levantine area and its tourist coast, the Costa del Sol and the lower valley of the Guadalquivir (Fig. 2).

\section{METHODOLOGY}

The tasks were performed in three phases, data collection, then the organization and classification of these, and finally preceded to statistical analysis and interpretation of results. The first step was the collection of data published on external sources of government information. The parameters studied for all beaches in Spain were: faecal bacteria, sediment, urbanization level and population.

The concentration of faecal bacteria in bathing water (Escherichia coli and Enterococcus) were obtained by Nayade [15], and sampling data were used since 2012-2015. These data have been processed in accordance with Directive 2006/7/EC and the related Royal Decree (RD 1341/2007), to obtain the values of E. coli and Enterococcus in each one of the beaches.

Following the methodology proposed by the directive Directive 2006/7/EC the 90-percentile and 95-percentile were calculated for the concentration of faecal bacteria in bathing water (Escherichia coli and Enterococcus).

Values calculated for each of the beaches, several samples of records with very high levels of concentration of bacteria were observed and were discarded, according to Article 6, paragraph 3 of the Directive. Finally, the data used for the study were those calculated according to the 95-percentile and filtered. 
The sedimentological composition of each of the beaches, is obtained according to the criteria established by MAGRAMA [16] classified according to the proportion in beach sediment type into 14 groups: [0] Sand, [1.1] Sand and Gravel, [1.2] Sand and Bowling, [2.1] Sand, Gravel, and Bowling, [2.2] Sand, Gravel, Bowling and Rock, [2.3] Sand, Gravel and Rock, [2.4] Sand, Bowling and Rock, [2.5] Sand and Rock, [3.1] Gravel, [3.2] Gravel and Bowling, [3.3] Gravel and Rock, [4.1] Bowling, [4.2] Rock and [4.3] Bowling and Rock. For statistical analysis, these groups were grouped into 3 types: Sandy beaches (group 0), sand and gravel beaches (groups from 1.1 to 2.5), and gravel beaches (groups of 3.1 to 4.3).

The urbanization level was also obtained as classified by MAGRAMA (2015) which follows the guidelines established by the study of Ariza et al. [14]. Urban beaches are considered those located in the core of the town, with at least $60 \%$ of the area urbanized influence (high density), urbanized (semi-urban) are those that are located in residential areas outside the core the municipality, with a maximum of $50 \%$ of the area urbanized influence (low density) and natural (isolated) are those outside the core of the municipality located closer to very low density urban areas (up to a maximum of $30 \%$ of the catchment area is urbanized), or uninhabited areas.

The population associated with the bathing season was obtained from the database of the INE [17]. This was added to the population by municipality passenger demand in bathing season (May, June, July and August). And the density of population in the municipalities was achieved with the ratio of the population and surface data in each of them.

First, using SPSS 20.0 statistical package has performed an analysis of the correlation between each of the factors studied. These correlations were performed for all the data analysed and grouped according to the data sea, Autonomous Community and Province. Then an analysis of variance (one-way ANOVA) was performed to study whether there were significant differences between the concentration of bacteria (E. coli and Enterococcus) and each of the factors considered (Urbanization level, sediment, population and density population in bathing season). When one-way ANOVA is used, the assumptions of normality of the dependent variable and the equal of variances in each group's assumptions have to be checked, being the assumption of equal variances between different subgroups the most important. The assumption of normality was determined using the Kruskal-Wallis and analysis of homogeneity of variance Levene's test was used.

In this study depending on the group used to analyse the data, in some cases, equal variances are met and not in others so to perform analysis ANOVA, different tests were used. When equality of variance was verified the Tukey's test was used, and the otherwise test Games Howell and nonparametric tests defined by test and Welch Brown-Forsythe.

Finally, an analysis and interpretation of the results were conducted, calculating indicators and measures that describe the dataset using descriptive as the arithmetic mean, standard deviation, standard error, confidence intervals for the average $95 \%$ and maximums and minimums.

\section{RESULTS}

First, the data studied in Spain are exposed, analysing correlations and ANOVA between faecal bacteria in bathing water and the rest of variables: Sea, Autonomous community, province, level of urbanization, sediment, population and density population associated with the bathing season. It is observed that the highest correlation is between the variables themselves dependent E. coli and Enterococcus, with an average $\mathrm{R}^{2}$ of 0.835 , being in the Atlantic area with the highest correlation $\mathrm{R}^{2}=0.917$ (Fig. 3). On the other hand according to Table 1 , 


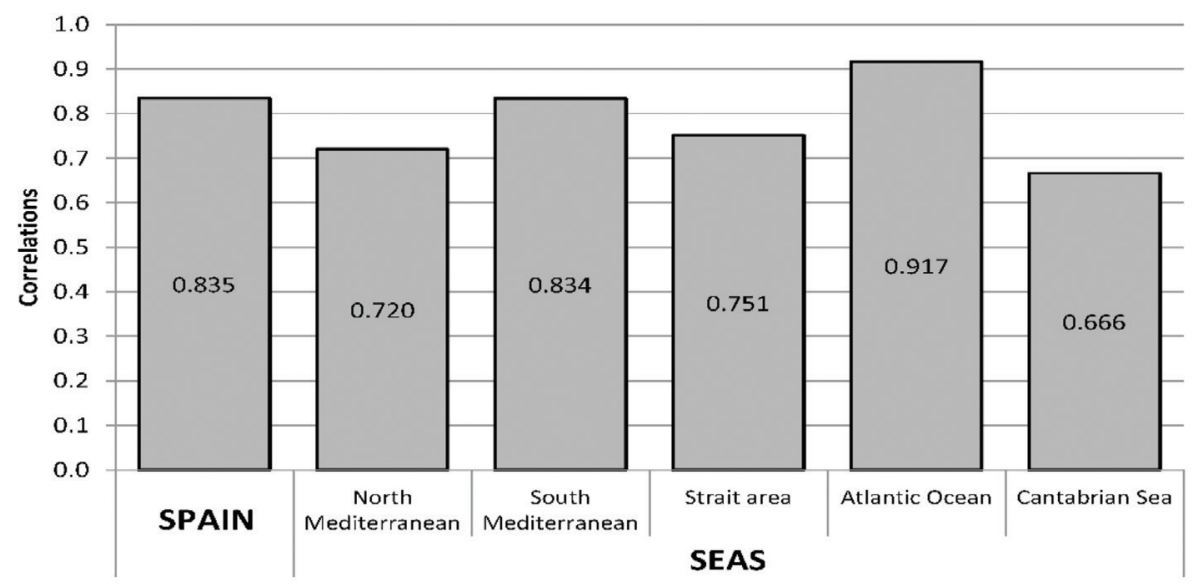

Figure 3: Correlations between E. coli and Enterococcus.

Table 1: Ratio of the average values of E. coli/Enterococcus $(\mathrm{EC} / \mathrm{E})$ by groups.

\begin{tabular}{lll}
\hline \multicolumn{2}{c}{ Groups } & Relation EC/E \\
\hline Sea & North Mediterranean & 1.74 \\
& South Mediterranean & 1.40 \\
& Strait area & 1.16 \\
& Atlantic Ocean & 1.97 \\
& Cantabrian Sea & 2.23 \\
Level of urbanization & Urban & 1.74 \\
& Semi-urban & 1.82 \\
Type of sediment & Natural & 1.88 \\
& Sand & 1.77 \\
& Sand and Gravel & 1.83 \\
& Gravel & 1.90 \\
\hline
\end{tabular}

among the relationship between the dependent and independent variables, population and population density are those that have lower correlation.

By studying ANOVA, information regarding the difference between the groups is obtained. For each dependent variable and factor has been found that the homogeneity of variance is not met, it has been found the homogeneity of variance is not met, so the Games-Howell test was applied and analysed whether there are significant differences at 5\%, for which the p-value was calculated. Table 2 shows the p-values for each variable and each factor, observing that when less than 0.05 , there are differences between the analysed groups.

The results of the relationship between E. coli/Enterococcus (EC/C) depending beaches grouped by sea, level of urbanization and type of sediment are shown in Table 1, finding higher ratios with the Cantabrian (2.23) and Atlantic (1.97), natural beaches (1.88) and gravel beaches (1.90). 
Urban Regeneration and Sustainability

Table 2: Correlations and ANOVAS between parameters.

\begin{tabular}{lccccc}
\hline & \multicolumn{2}{c}{ Correlations } & & \multicolumn{2}{c}{ ANOVAS } \\
\cline { 2 - 3 } \cline { 6 - 7 } & E. coli & Enterococcus & & E. coli & Enterococcus \\
\hline Sea & 0.266 & 0.142 & & 0.000 & 0.000 \\
Autonomous community & 0.058 & -0.040 & & 0.007 & 0.009 \\
Province & 0.277 & 0.151 & & 0.001 & 0.002 \\
Level of urbanization & -0.078 & -0.078 & & 0.006 & 0.015 \\
Type of sediment & -0.100 & -0.081 & & 0.001 & 0.010 \\
Population (hab) & -0.027 & -0.015 & & $*$ & $*$ \\
Population density (hab/km $\left.{ }^{2}\right)$ & 0.015 & 0.033 & & $*$ & $*$ \\
E. coli & 1.000 & 0.835 & & - & - \\
Enterococcus & 0.835 & 1.000 & & - & - \\
\hline
\end{tabular}

* These parameters cannot be analysed by ANOVA, to be specific values for each of the beaches, and not be separated into groups.

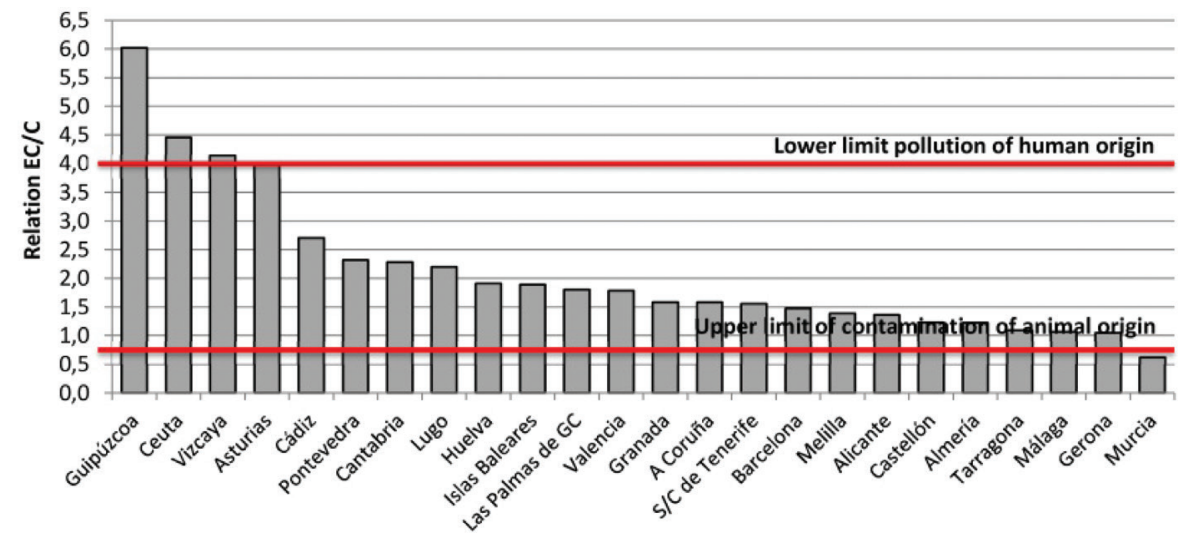

Figure 4: Ratio E. coli/Enterococcus by provinces.

The EC/C ratio catalogued by provinces is shown in Fig. 4. As shown Guipúzcoa, Ceuta and Vizcaya exceed the limit for the contamination of human origin and Murcia is on the threshold of contamination of animal origin. When the ratio EC/E is greater than 4, you are in the presence of faecal contamination from human sources, and when this ratio is less than 0.7 , contamination is of animal origin.

Finally in Fig. 5, the average values of concentration of bacteria in bathing waters are represented. In Fig. 5a, classification is made by sediment type, revealing that composite sand beaches only reach peak values (93.9 and $47.6 \mathrm{CFU} / 100 \mathrm{ml}$ for E. coli and Enterococcus respectively) while gravel have the lowest concentrations (48.0 and 29.3 CFU/100 ml respectively). In addition, the classification by the level of urbanization in the vicinity of the beach 

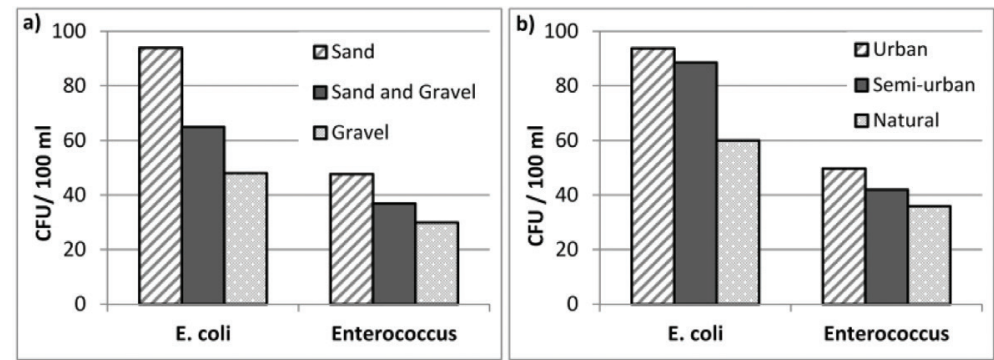

Figure 5: Faecal bacteria according to sediment type (a) and level of urbanization (b) from the beach.

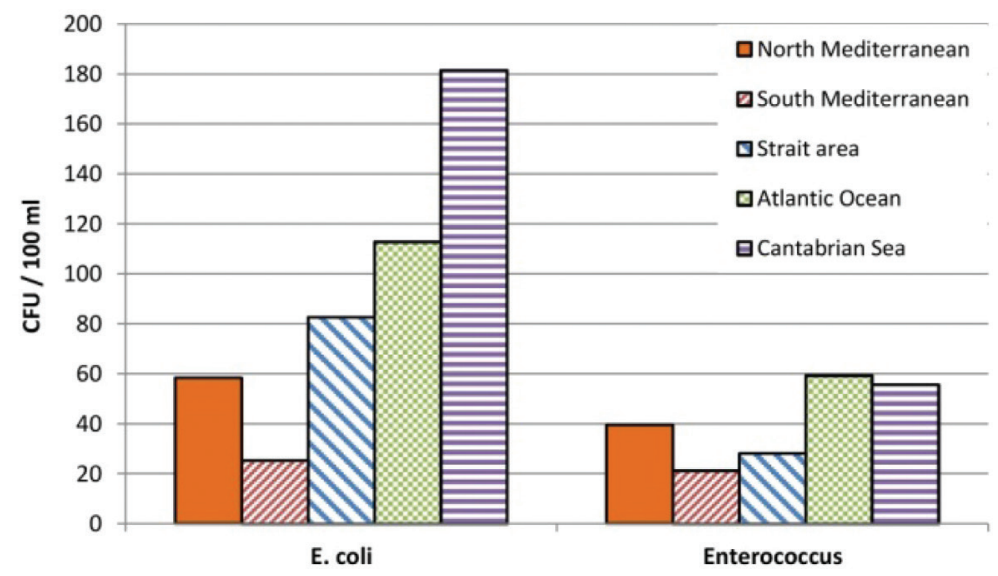

Figure 6: Mean values of faecal bacteria depending on the sea.

is shown in Fig. 5b, revealing that the urban beaches reach peak values (93.7 and $49.7 \mathrm{CFU} / 100 \mathrm{ml}$ for E. coli and Enterococcus, respectively) and natural lower (60 and $35.9 \mathrm{CFU} / 100 \mathrm{ml}$, respectively).

In Fig. 6, it can be seen that the concentrations of E. coli and Enterococcus vary considerably by zoning. The area with the highest concentrations is the Cantabrian Sea (181.4 and $55.7 \mathrm{CFU} / 100 \mathrm{ml}$ for E. coli and Enterococcus respectively) and the area with lowest values is found in the South Mediterranean Sea (25.4 and 21.1 CFU/100 ml, respectively).

\section{DISCUSSION}

A study of faecal bacteria in 1,392 beaches of the Spanish coast, and its relationship with those related to the urban environment of the beach has been performed. For which, factors such as the degree of urbanization, sediment type, population, population density, sea, autonomous community and province for each of the beaches of Spain have been studied by analysing correlations and whether there are significant differences in bacteria among different subgroups defined for each of the factors.

The results of mathematical analysis show that the direct linear relationship between the dependent and independent variables are not very good (Table 2). It can be affirmed that these 
variables do not influence separately linearly in the evolution of bacteria but it is interrelated and jointly cause an effect differentiating on E. coli or Enterococcus, depending on the area in which the waters are located and sediment type. However, it is observed that the best relationships are shown between the dependent variables with an R2 of 0.83 for the set of all the beaches analysed. By dividing the beaches according to the five seas or areas, the correlation between the two bacteria is higher on the Atlantic Ocean (0.917) and lowest in the Cantabrian Sea (0.67) (Fig. 3). This is because in the intestines of humans and warm-blooded animals, the concentration of $E$. coli is generally about one order of magnitude greater than that Enterococcus, like later in their dregs [18]. Instead, survival rates of both bacteria are different, so the ratio is not fixed, and is altered by other variables. The Enterococcus have important advantages: they tend to survive longer than $E$. coli in aquatic environments, and are more resistant to drying and chlorination [18]. Likewise, the E. coli in seawater is a bacterium that survives less time, although according to the characteristics of the medium can be reproduced on it, so that the variability of concentration is more marked in this bacterium. Another variable to consider is the sunlight, as this kills the bacteria present in the upper layers of the water, if transparency requirements are satisfied [19]. Thus, in areas like Southern Mediterranean, E. coli/Enterococcus $(\mathrm{EC} / \mathrm{E})$ ratio is 1.2 , however, in the Cantabrian Sea is increased to 2.2 (Table 1). The same happens if this study is carried out by sediment type and level of urbanization, noting that the natural beaches the ratio EC/E is lower in natural beaches than in urban beaches (Table 1).

The use of the ratio EC/E can be very useful for the determination of human or animal faecal contamination. It has been suggested that the amounts of thermo tolerant coliforms and faecal Enterococcus which are discharged by humans are significantly different from those discharged by animals $[20,21]$. When the ratio EC/E is greater than 4 you are in the presence of faecal contamination from human sources, and when this ratio is less than 0.7 contamination is of animal origin. However, in the range between 0.7 and 4 the source of contamination cannot be interpreted the source of contamination, and can even be a mixed faecal contamination, that is, where there is presence of human and animal dregs [22, 23]. In Fig. 4, it is observed that Guipúzcoa, Vizcaya and Ceuta have a ratio greater than 4, so might be said that its origin is human being Murcia the only province where contamination could be of animal origin.

Furthermore, ANOVA study has shown that there are significant differences between bacteria and the various groups considered in the factors studied (Table 1). Thus, it can be observed on beaches depending on the type of sediment found [13], and there is a clear differentiation (Fig. 5), they are always sand which provide higher values of both bacteria (E. coli to $93,92 \mathrm{CFU} / 100 \mathrm{ml}$ and Enterococcus $47.65 \mathrm{CFU} / 100 \mathrm{ml}$ ) and generally gravel beaches have the least (48.04 and $29.91 \mathrm{CFU} / 100 \mathrm{ml}$, respectively). This may be due to several factors: i) The faecal bacteria, particularly E. coli persists and reproduces in the sand, allowing to re-enter the water column, in areas with tidal [7,8], and is seen as the areas with a large tidal range (Cantabrian, Atlantic and Strait) values of these bacteria are higher than in other areas (Fig. 6). ii) The sandy beaches due to the type of failure that occurs in them, giving rise to a haze in waters which prevents ultraviolet radiation and inactivate the bacteria, i.e., the presence of sand in the water helps survival of the bacteria, which has been tested previously by other authors $[9,10]$, to positively correlate the turbidity of the water with the abundance of enteric bacteria. On the beaches with cleaner waters, the mortality E. coli is faster [24], thus the beaches composed exclusively of gravel allow for greater transparency of the water, having less sediment suspended in the water 
column and thus enable the UV rays disinfected [25], which is directly related to the type of failure that occurs in it. As indicated by Longuet-Higgins and Parkin [26], Sherman et al. [27], this type of beaches that are more reflective of sand, allowing dilution into the sea (Fig. 5a).

On the other hand, if it is classified to all the beaches depending on the level of urbanization [16] both bacteria always remain in the same pattern (Fig. 5b). It is noted that urban areas are the most affected by pollution of these microorganism $(93.76 \mathrm{CFU} / 100 \mathrm{ml}$ for $E$. coli and 49.76 CFU/100 ml Enterococcus), while natural, the least (60.01 and $3591 \mathrm{CFU} / 100 \mathrm{ml}$, respectively). This result could be evident from the beginning, since the most accessible beaches are hosting as many swimmers, with dirt that entails as so says Ariza et al. [11]. However, the study of population density and population associated with the bathing season, has not been a direct correlation between the numbers of possible users of the beach with the concentration of bacteria in the water (Table 2).

\section{CONCLUSION}

The study of the quality of bathing water in Spanish coast provides a clear idea of how it affects the type of sediment that forms the beach, its environment and location although the correlation between bacteria and other variables do not reach too high values.

The correlation between the bacterium Escherichia coli and Enterococcus is reaching the highest value of all, with an R2 of 0.83 , due to its origin, although the study of the variability of this data by area is a pending task for future studies due to the multitude of factors that can affect.

In addition, the type of sediment that forms the beach is crucial to assess the quality of bathing water and the type of failure that causes the coast. The sandy beaches serve as a natural reservoir for the proliferation of bacteria, including $E$. coli, which is to be affected by the tidal contaminate water. The type of break on the sandy beaches, which tend to be dissipative, produces turbulence suspending the sediment into the water column and causing turbidity. This leads to a worst inactivation of bacteria by ultraviolet rays.

It is also noted that the beach water located near urban areas is poor quality. Although wastewaters from human origin are treated by wastewater treatment plants, the activities of the population generate discharges different focuses that will lead to the sea. Therefore, much more are exposed to pollution in urban and semi-urban beaches, natural beaches. Between urban and semi-urban beaches, the variation in concentrations is small and quite different from the natural. It has been demonstrated how the water of urban beaches and sandy beaches are those found most polluted faecal bacteria.

No relationship between sediment type and degree of urbanization is observed. Each of these variables separately determines the concentration of bacteria on the beaches, where the sediment which reaches higher correlation with both bacteria ( 0.100 to 0.081 for E. coli and Enterococcus) against the degree of urbanization ( 0.078 for both bacteria).

Finally add that there are a lot of factors that affect the dilution and inactivation of faecal bacteria in the sea, such as hours of sunshine, UV, temperature and salinity, rainfall in the area, height wave and wind or the presence of Posidonia oceanica. Although these factors have not been studied, yes they have been taken into account in the understanding of the results according to the areas, communities or provinces, and it is intended to study in future research, opening new paths to research on the quality of bathing water on the coast, both in Spain and extrapolated to any other territory. 


\section{ACKNOWLEDGEMENTS}

The authors thank the Ministerio de Agricultura, Alimentación y Medio Ambiente, the Instituto Nacional de Estadística for the information provided.

\section{REFERENCES}

[1] Sardá, R. \& Fluviá, M., Tourist development in the costa brava (Girona, Spain): a quantification of pressures on the coastal environment. In Perspectives on Integrated Coastal Zone Management, eds. W. Salomons, R.K. Turner, L.D. Lacerda \& S. Ramachandran, Springer Berlin Heidelberg: Berlin, Heidelberg, pp. 257-277, 1999 http://dx.doi.org/10.1007/978-3-642-60103-3_15

[2] Bosch, A., Lucena, F., Giron, R. \& Jofre, J., Survey of viral pollution in Bes\&\#xf3;s river (Barcelona). Journal (Water Pollution Control Federation), 58(1), pp. 87-91, 1986.

[3] Wyn-Jones, A. \& Sellwood, J., Enteric viruses in the aquatic environment. Journal of Applied Microbiology, 91(6), pp. 945-962, 2001. http://dx.doi.org/10.1046/j.1365-2672.2001.01470.x

[4] Nasser, A.M., Prevalence and fate of hepatitis A virus in water. Critical Reviews in Environmental Science and Technology, 24(4), pp. 281-323, 1994. http://dx.doi.org/10.1080/10643389409388470

[5] Callahan, K.M., Taylor, D.J. \& Sobsey, M.D., Comparative survival of hepatitis A virus, poliovirus and indicator viruses in geographically diverse seawaters. Water Science and Technology, 31(5-6), pp. 189-193, 1995. http://dx.doi.org/10.1016/0273-1223(95)00264-N

[6] Gantzer, C., Maul, A., Audic, J., \& Schwartzbrod, L., Detection of infectious enteroviruses, enterovirus genomes, somatic coliphages, and Bacteroides fragilis phages in treated wastewater. Applied and Environmental Microbiology, 64(11), pp. 4307-4312, 1998.

[7] Yamahara, K.M., Layton, B.A., Santoro, A.E \& Boehm, A.B., Beach sands along the California coast are diffuse sources of fecal bacteria to coastal waters. Environmental Science \& Technology, 41(13), pp. 4515-4521, 2007. http://dx.doi.org/10.1021/es062822n

[8] Alm, E.W., Burke, J. \& Hagan, E., Persistence and potential growth of the fecal indicator bacteria, Escherichia coli, in shoreline sand at lake huron. Journal of Great Lakes Research, 32(2), pp. 401-405, 2006. http://dx.doi.org/10.3394/0380-1330(2006)32[401:PAPGOT]2.0.CO;2

[9] Haugland, R.A., Siefring, S.C., Wymer, L.J., Brenner, K.P. \& Dufour, A.P., Comparison of enterococcus measurements in freshwater at two recreational beaches by quantitative polymerase chain reaction and membrane filter culture analysis. Water Research, 39(4), pp. 559-568, 2005. http://dx.doi.org/10.1016/j.watres.2004.11.011

[10] Mallin, M.A., Williams, K.E., Esham, E.C. \& Lowe, R.P., Effect of human development on bacteriological water quality in coastal watersheds. Ecological Applications, 10(4), pp. 1047-1056, 2000. http://dx.doi.org/10.1890/1051-0761(2000)010[1047:EOHDOB]2.0.CO;2

[11] Ariza, E., Jimenez, J.A., Sarda, R., Villares, M., Pinto, J., Fraguell, R., Roca, E., Marti, C., Valdemoro, H. \& Ballester, R., Proposal for an integral quality index for urban and urbanized beaches. Environmental Management, 45(5), pp. 998-1013, 2010. http://dx.doi.org/10.1007/s00267-010-9472-8 
[12] Winter, J. \& Duthie, H., Effects of urbanization on water quality, periphyton and invertebrate communities in a southern Ontario stream. Canadian Water Resources Journal, 23(3), pp. 245-257, 1998. http://dx.doi.org/10.4296/cwrj2303245

[13] Pye, K., The nature and geomorphology of coastal shingle. Ecology \& Geomorphology of Coastal Shingle, pp. 2-22, 2001.

[14] Ariza, E., Jiménez, J.A. \& Sardá, R., A critical assessment of beach management on the Catalan coast. Ocean \& Coastal Management, 51(2), pp. 141-160, 2008. http://dx.doi.org/10.1016/j.ocecoaman.2007.02.009

[15] Nayade, Sistema de Información Nacional de Aguas de Baño, 2015, available at http:// nayade.msc.es/Splayas/home.html

[16] MAGRAMA, Ministerio de Agricultura, Alimentación y Medio Ambiente, Guía de Playas, 2015.

[17] INE. Instituto Nacional de Estadística, 2015, available at http://www.ine.es/

[18] Prescott, L.M., Harley, J.P. \& Klein, D.A., Microbiology: Tata Mc Kathleen Park Talaro and Barry Chess, Foundations in Microbiology, 8th edn., Mc Graw-Hill companies: New York, 2002.

[19] Whitman, R.L., Nevers, M.B., Korinek, G.C. \& Byappanahalli, M.N., Solar and temporal effects on escherichia coli concentration at a lake michigan swimming beach. Applied and Environmental Microbiology, 70(7), pp. 4276-4285, 2004. http://dx.doi.org/10.1128/AEM.70.7.4276-4285.2004

[20] Tchobanoglous, G. \& Burton, F.L., Wastewater engineering. Management, 7, pp. 1-4, 1991.

[21] Meeroff, D.E., Bloetscher, F., Bocca, T. \& Morin, F., Evaluation of water quality impacts of on-site treatment and disposal systems on urban coastal waters. Water Air and Soil Pollution, 192(1), pp. 11-24, 2008. http://dx.doi.org/10.1007/s11270-008-9630-2

[22] Marchand, E.O., Microorganismos indicadores de la calidad del agua de consumo humano en Lima Metropolitana, Tesis]. Lima, Perú: Escuela Académico Profesional de Ciencias Biológicas, 2000.

[23] Coyne, M. \& Howell, J., The fecal coliform/fecal streptococci ratio (FC/FS) and water quality in the bluegrass region of Kentucky. Soil Science News and Views (USA), 5(9), p. 4, 1994.

[24] Garzio-Hadzick, A., Shelton, D.R., Hill, R.L., Pachepsky, Y.A., Guber, A.K. \& Rowland, R., Survival of manure-borne E. coli in streambed sediment: Effects of temperature and sediment properties. Water Research, 44(9), pp. 2753-2762, 2010. http://dx.doi.org/10.1016/j.watres.2010.02.011

[25] Salcedo, I., Andrades, J.A., Quiroga, J.M. \& Nebot, E., Desinfección de aguas residuales urbanas mediante radiación ultravioleta: aplicación el la EDAR de Jerez de la Frontera. Tecnología del Agua, (227), pp. 42-56, 2002.

[26] Longuet-Higgins, M. \& Parkin, D., Sea waves and beach cusps. Geographical Journal, pp. 194-201, 1962. http://dx.doi.org/10.2307/1793470

[27] Sherman, D.J., Orford, J.D. \& Carter, R., Development of cusp-related, gravel size and shape facies at Malin Head, Ireland. Sedimentology, 40(6), pp. 1139-1152, 1993. http://dx.doi.org/10.1111/j.1365-3091.1993.tb01384.x 